\title{
Female effect in sheep. II. Role of volatile substances from the sexually receptive female; implication of the sense of smell
}

\author{
R Gonzalez *, F Levy, P Orgeur, P Poindron, JP Signoret **
}

Laboratoire de Comportement Animal, INRACNRS, URA 1291, Nouzilly 37380 Monnaie, France

(Received 20 July, 1990; accepted 10 December, 1990)

\begin{abstract}
Summary - The importance of olfactory cues in inducing luteinizing hormone and testosterone secretion as a response to stimulation by sexually receptive ewes has been tested. In sexually experienced rams, olfactory stimulation with urine, wool and vaginal secretions from sexually receptive females placed in a mask did not induce an endocrine response. The female-induced secretion of $\mathrm{LH}$ and testosterone was similar in anosmic, sham-operated and in control rams. These results show that olfactory cues are not necessary in the mediation of interindividual stimulation of endocrine response in the sexually experienced ram.
\end{abstract}

\section{LH / testosterone / female effect / ram / olfaction}

Résumé - Effet femelle chez les ovins. II. Rôle des substances volatiles produites par une femelle sexuellement réceptive; implication du sens de l'odorat. Dans une première expérience, 36 béliers lle-de-France, sexuellement expérimentés, ont été répartis en 3 groupes : témoins non stimulés, stimulés par la mise en présence d'une femelle réceptive, ou par la présentation simultanée de ces substances volatiles, émises par la toison, l'urine et les sécrétions vaginales de brebis sexuellement réceptives. Les taux plasmatiques de $\mathrm{LH}$ et de testostérone ont été mesurés à un intervalle de 20 min pendant $6 \mathrm{~h}$. La stimulation par ces substances volatiles, réalisée pendant les 3 dernières $h$ des prélèvements sanguins, n'induit aucune modification des sécrétions endocrines, alors que la présence de brebis réceptives accroît la fréquence des épisodes de sécrétion de $\mathrm{LH}$ et le taux de testostérone. Dans une seconde expérience, 47 béliers ont été répartis en 4 groupes : témoins non stimulés, témoins stimulés, anosmiques ou ayant subi une opération fantôme. L'anosmie a été induite par irrigation au sulfate de zinc (pour détruire la muqueuse olfactive) associée à une section du nerf voméronasal. Les effets de la stimulation par des femelles réceptives, mesurés comme dans la première expérience, sont identiques chez les sujets anosmiques, les témoins fantômes ou intacts. Ces résultats indiquent que l'odorat ne semble pas nécessaire à la stimulation des réponses neuro-endocrines du bélier sexuellement expérimenté, par la présence de femelles réceptives.

\section{LH / testostérone / effet femelle / ovin / odorat}

\footnotetext{
* Present address: INTA, Sheep Reproduction Research Group, CC 277, 8400 Bariloche, Argentina.

** Correspondence and reprints.
} 


\section{INTRODUCTION}

Olfaction is involved in most of the effects that males have on female physiology (Vandenbergh, 1988). In sheep, the male's presence induces rapid changes in the pattern of pituitary hormone secretion in the female: the presentation of the ram to anestrous ewes induces an LH pulse in a matter of minutes (Martin et al, 1978; Poindron et al, 1980). This effect can be mimicked by the odor of ram's fleece or fleece extract (Cohen-Tannoudji et al, 1989). A similar effect has been described in the male: the presence of sexually receptive females induces an increase in $\mathrm{LH}$ and testosterone levels (mice: Coquelin and Bronson, 1980; rats: Kamel et al, 1977; hamsters: Macrides et al, 1974; bulls: Katongole et al, 1971; rams: Sanford et al, 1974). However, contrary to what is known about the female, little is known about the sensory cues involved in the female effect on males, even though the possible role of olfactory cues has been proposed (Schanbacher et al, 1987; Gonzalez et al, 1988). The aim of this study was to experimentally determine the importance of olfactory cues in the LH and testosterone response of rams to sexually receptive ewes. The first experiment was designed to test whether the stimulation with potential sources of pheromones (urine, wool, and vaginal secretions) from sexually receptive females was sufficient to induce an endocrine response in the male. In the second experiment, we investigated whether the sense of smell was necessary for the female effect.

\section{MATERIALS AND METHODS}

\section{Animals}

Adult and sexually experienced lle-de-France rams were used. They had been isolated from contact with females for 1 month prior to the experiment. Sexual receptivity was induced in ovariectomized lle-de-France ewes treated with progesterone $(100 \mathrm{mg} \mathrm{im})$ for $5 \mathrm{~d}$ and then injected with estradiol benzoate $(50 \mu \mathrm{g} \mathrm{im})$ on the 7 th $\mathrm{d}$. Animals were kept indoors under natural light conditions, and fed a constant diet of dehydrated lucerne and maize, plus straw and mineral complement ad libitum.

\section{Hormone assays}

The effect of stimulation was assessed by measuring the circulating $\mathrm{LH}$ and testosterone levels. Blood samples were taken continuously from rams at 20-min intervals for a 3 -h prestimulation period and for $3 \mathrm{~h}$ during stimulation. Blood samples were kept at $4{ }^{\circ} \mathrm{C}$ before centrifugation and thereafter plasma was stored at $-15^{\circ} \mathrm{C}$. LH and testosterone concentrations were each measured (Pelletier et al, 1982; Garnier et al, 1978, respectively) in a single assay by direct RIA methods on duplicate serum samples. The intraassay coefficients of variation and the levels of detection were $8.3 \%$ and $100 \mathrm{pg} / \mathrm{ml}$ and $6.6 \%$ and $200 \mathrm{pg} / \mathrm{ml}$ for $\mathrm{LH}$ and testosterone respectively. Purified OLH CY 1051 ( $=2.1 \times \mathrm{NIH}$-LHS1) was used as standard. LH peaks were identified using the Pulsar algorithm program (Merriam and Wachter, 1982). The smoothing window used to compute the theoretical baseline was 10 samples $(200 \mathrm{~min})$.

\section{Statistical analysis}

LH pulse frequency data was analyzed between groups by the Mann-Whitney U-test, and intragroup comparisons of $\mathrm{LH}$ pulse frequency between pretreatment and treatment periods by the Wilcoxon matched-pair test [34]. All the reported significant differences are one-tailed.

ANOVA tests using the SYSTAT statistical computer program (Wilkinson, 1988) were performed on the mean testosterone concentrations between groups. The beginning of the "treatment period" was delayed by $\mathbf{4 0} \mathrm{min}$ for determining testosterone values to take into account the lag in gonadal response following an LH pulse (Terqui et al, 1980). Intragroup com- 
parisons were made between pretreatment and treatment periods by repeated measure analysis (Stevens, 1986). The accepted level of significance was $P<0.05$.

\section{EXPERIMENT 1}

\section{Methods}

\section{Experimental groups and procedure}

Thirty-six adult and sexually experienced lle-de-France rams were allocated at random into 3 groups of 12 animals: i), stimulated by female odor; ii), stimulated by sexually receptive females; and iii), unstimulated controls.

The classical sources of sexual pheromones are urine or vaginal secretions. However, in the female, the odor from ram's fleece stimulates $\mathrm{LH}$ release and ovulation in the anestrous ewe (Knight and Lynch, 1980; Signoret and Lindsay, 1982). Therefore, we chose to associate these 3 substances to test their effect on rams. Olfactory stimulation was performed by fitting the rams with masks as described in the ewe by Cohen-Tannoudji et al (1986). To verify that fitting the masks did not affect spontaneous LH pulsatility pattern, in a pre-experimental phase 21 of the rams (7 per experimental group) were fitted with a mask containing a sterile pad for the last 3 $h$ of the 6-h period of blood sampling at 20min intervals.

For the experiment, each group of rams was placed in a $10-\mathrm{m}^{2}$ pen which was visually isolated from the others, and blood was sampled for $6 \mathrm{~h}$ at 20-min intervals from 09.00 am onwards. Olfactory stimulation or introduction of females took place after $3 \mathrm{~h}$ of blood sampling. The masks contained $2 \mathrm{ml}$ urine, $2 \mathrm{~g}$ wool and a cotton pad impregnated with vaginal secretions from females induced into sexual receptivity by steroid treatment. Urine was obtained from 4 sexually receptive ewes by reflex emission after induced apnea a few min before stimulation began, and pooled. Wool was clipped from their neck and back. In 12 females, sterile cotton pads were introduced deeply within the vaginal and left for $30 \mathrm{~min}$. Then each pad was cut into 4 equal pieces and distributed in 4 different masks. In this way, each olfactorystimulated ram received an odor from 4 different sexually receptive ewes. Rams were trained to accept fitting of the masks containing one sterile cotton pad 5 times for 1 , $2,3,4$ and $5 \mathrm{~h}$ respectively during the week before the experiment.

\section{Results}

Fitting the rams with a mask containing a sterile cotton pad did not affect any hormonal parameters considered when compared with the 3 preceding $h$. Olfactory stimulation with odors from sexually receptive females did not affect $\mathrm{LH}$ or testosterone levels (table I). As in previous experiments, stimulation by sexually receptive females increased LH pulse frequency and testosterone values. No hormonal parameter changed in unstimulated controls.

\section{EXPERIMENT 2}

In this experiment, rams with an entirely blocked olfactory system were compared to sham-operated and intact rams when in contact with estrous females. 
Table I. Mean LH pulse frequency and mean testosterone values (standard deviation in brackets) for 12 rams stimulated by the odor of urine, vaginal secretion and wool of sexually receptive ewes (Odor), for 12 rams stimulated by sexually receptive ewes (Ewes) and 11 unstimulated control rams (Control).

\begin{tabular}{|c|c|c|c|c|c|}
\hline \multirow{4}{*}{$\begin{array}{l}\text { Mean LH pulse } \\
\text { Frequency } \\
\text { per ram } / 3 \mathrm{~h}\end{array}$} & \multirow{4}{*}{$\begin{array}{l}\text { Group } \\
\text { Odor } \\
\text { Ewe } \\
\text { Control }\end{array}$} & \multicolumn{2}{|c|}{$\begin{array}{l}\text { Pretreatment } \\
\text { period }\end{array}$} & \multicolumn{2}{|c|}{$\begin{array}{l}\text { Treatment } \\
\text { period }\end{array}$} \\
\hline & & 0.66 & $(0.32)^{a}$ & 0.83 & $(0.35)^{a}$ \\
\hline & & 0.50 & $(0.26)^{a}$ & 1.75 & $(0.71)^{\mathrm{b}}$ \\
\hline & & 0.54 & $(0.26)^{\mathrm{a}}$ & 0.90 & $(0.42)^{\mathrm{a}}$ \\
\hline Testosterone & Odor & 2.07 & $(1.38)^{a}$ & 2.24 & $(1.57)^{\mathrm{a}}$ \\
\hline mean level & Ewe & 1.80 & $(1.31)^{\mathrm{a}}$ & 4.09 & $(2.90)^{\mathrm{b}}$ \\
\hline $\mathrm{ng} / \mathrm{ml}$ plasma & Control & 1.33 & $(0.79)^{a}$ & 2.08 & $(1.99)^{a}$ \\
\hline
\end{tabular}

Different letters in the same row and for a given variable in the same columns indicate statistically significant differences $(P<0.05)$.

\section{Methods}

\section{Experimental groups and procedure}

Forty-seven adult sexually experienced rams were allocated at random to 4 experimental groups: anosmic, sham-operated, stimulated intact controls and nonstimulated intact controls (12 animals per group, except for the sham-operated group) (11 animals). Rams were kept together except for $15 \mathrm{~d}$ during the treatments to induce anosmia: anosmic and sham-operated groups were separated 45 $d$ before the experiment began. The technique described in sheep by Poindron (1974) was used for destruction of nasal mucosa and repeated to induce permanent anosmia. Three $d$ after the second treatment with zinc sulfate, $1 \mathrm{~cm}$ of each vomeronasal nerve was removed under visual control, according to the surgical method described in the ewe by CohenTannoudji et al (1989). One month was allowed for recovery before the experiment began. Anosmia was verified by repulsion test (Poindron, 1974). Anosmic rams were killed $10 \mathrm{~d}$ after the end of the experiment, and the completeness of the lesion established by careful dissection. The rams of the sham-operated group underwent the same treatment as the anosmic group except for nasal infusion with saline, and the surgical procedure was stopped before nerve sectioning.

\section{Experimental protocol}

The experiment took place on 2 successive days in March, and half of the animals in each group were used for each session. The intact non-stimulated animals were housed in visual isolation from the others, in a $10-\mathrm{m}^{2}$ pen. The rams from the stimulated groups were placed together in 2 contiguous $10-\mathrm{m}^{2}$ pens. Blood samples were taken from all animals at 20-min, intervals over a 6 -h period starting at 09.00 am. Three sexually receptive ewes were introduced into each pen after $3 \mathrm{~h}$ of blood sampling and remained with the males for the following $3 \mathrm{~h}$. 


\section{Results}

The hormonal parameters considered were not affected by anosmia: no significant difference appeared between groups during the pretreatment period. The introduction of the sexually receptive female significantly increased LH pulse frequency patterns in anosmic, sham-operated and intact rams. The absence of any increase in intact non-stimulated rams resulted in a significant difference with the $\mathbf{3}$ stimulated groups. Testosterone mean values increased in all stimulated groups, and were significantly different from those observed in the intact non-stimulated group (table II).

\section{DISCUSSION}

Olfactory stimulation with wool, urine and vaginal secretion from sexually receptive ewes was found to be insufficient to induce an endocrine response in rams under our experimental conditions. Such a result is contrary to what has been described in rodents: plasma LH and/or testosterone levels increase after sniffing female urine in mice (Maruniak and Bronson, 1976), the odor of female litter in rats (Kamel et al, 1977 ) or vaginal secretions in hamsters (Macrides et al, 1974). In our experiment, we used a mask for olfactory stimulation, which could have disturbed the endocrine reactions. However, with the same technique used in female sheep, no inhibition of spontaneous release of $\mathrm{LH}$ has been observed, and the sexual pheromones from the ram are as efficient as the male itself in inducing $\mathrm{LH}$ release in anestrous ewes (Cohen-Tannoudji et al, 1986, 1989).

In our experimental procedure, only volatile substances were used to stimulate the rams: an insufficient stimulation of the accessory system cannot be excluded. In rodents, this system mediates the stimulatory effect of pheromones (Wysocki, 1979; Wysocki et al, 1983), and non-volatile substances need to be dissolved in liquids in

Table II. Mean LH pulse frequency and mean testosterone values (standard deviation in brackets) from 12 anosmic rams stimulated IA/S), 11 sham-operated rams stimulated (S/S), and 12 intact rams stimulated (I/S), stimulated by sexually receptive females, and 12 intact non-stimulated rams (I/NS).

\begin{tabular}{|c|c|c|c|c|c|}
\hline \multirow[b]{2}{*}{$\begin{array}{l}\text { LH mean pulse } \\
\text { frequency } \\
\text { per ram } / 3 \mathrm{~h}\end{array}$} & \multirow{2}{*}{$\begin{array}{l}\text { Group } \\
\text { AVS } \\
\text { S/S } \\
\text { I/S } \\
\text { I/NS }\end{array}$} & \multicolumn{2}{|c|}{ Pretreatment period } & \multicolumn{2}{|c|}{ Treatment period } \\
\hline & & $\begin{array}{l}0.16 \\
0.41 \\
0.50 \\
0.50\end{array}$ & $\begin{array}{l}(0.19)^{\mathrm{a}} \\
(0.46)^{\mathrm{a}} \\
(0.33)^{\mathrm{a}} \\
(0.23)^{\mathrm{a}}\end{array}$ & $\begin{array}{l}0.83 \\
1.08 \\
1.25 \\
0.16\end{array}$ & $\begin{array}{l}(0.46)^{\mathrm{b}} \\
(0.53)^{\mathrm{b}} \\
(0.52)^{\mathrm{b}} \\
(0.19)^{\mathrm{a}}\end{array}$ \\
\hline $\begin{array}{l}\text { Testosterone } \\
\text { mean level } \\
\text { ng/ml plasma }\end{array}$ & $\begin{array}{l}\text { A/S } \\
\text { S/S } \\
\text { I/S } \\
\text { I/NS }\end{array}$ & $\begin{array}{l}1.10 \\
1.45 \\
1.75 \\
1.61\end{array}$ & $\begin{array}{l}(0.75)^{\mathrm{a}} \\
(0.90)^{\mathrm{a}} \\
(1.01)^{\mathrm{a}} \\
(1.00)^{\mathrm{a}}\end{array}$ & $\begin{array}{l}3.16 \\
3.35 \\
3.75 \\
1.25\end{array}$ & $\begin{array}{l}(1.84)^{\mathrm{b}} \\
(1.84)^{\mathrm{b}} \\
(1.35)^{\mathrm{b}} \\
(0.90)^{\mathrm{a}}\end{array}$ \\
\hline
\end{tabular}

Different letters in the same row and for a given variable in the same columns indicate statistically significant differences $(P<0.05)$. 
order to reach the vomeronasal organ (Wysocki et al, 1980). If this is the case in sheep, a direct contact with the fluids containing the active chemicals would be necessary for a complete stimulation of the accessory system. However, the mask used in our experiment enforced a distance of $1-2 \mathrm{~cm}$ between the muzzle and the pheromone source. Therefore the lack of response could be due to insufficient stimulation. As this is not the case with the male effect in female sheep (CohenTannoudji et al, 1989), it may also indicate that the male effect in ewes and the female effect in rams are controlled by different mechanisms.

As already observed by Lindsay (1965), sexual behavior did not differ between the 3 groups, with the exception of a reduction in sniffing and flehmen frequency in anosmic rams. Blocking the entire olfactory function did not change the $\mathrm{LH}$ and testosterone response of rams to the presence of sexually receptive females, demonstrating that the sense of smell is not necessary for the female effect in sheep, at least under our experimental conditions using sexually experienced rams. A similar situation has been observed in the $\mathrm{LH}$ response of females to the presence of males or "male effect" after surgical removal of the olfactory bulbs in sheep (CohenTannoudji et al, 1986) and in the anosmic doe after zinc sulfate treatment (Chemineau et al, 1986). In such cases, however, olfactory stimulation by male odor (fleece, or fleece extracts) is effective in inducing the endocrine response (Knight and Lynch, 1980; Signoret and Lindsay, 1982). But when the olfactory function is eliminated, other sensory cues can compensate for the absence of chemical information.

The good agreement between the results of the 2 experiments suggests that the olfactory function does not play a critical role in the female effect in the sexually experienced ram.

\section{ACKNOWLEDGMENTS}

The authors are indebted to A Locatelli for performing the surgery. We wish to thank $E$ Archer, D Blache, A Boissy, V Picketty and G Venier for technical assistance, and also thank the Laboratoire des Dosages Hormonaux, INRA Nouzilly for assistance with radio-immunoassays, and $Y$ Combarnous for providing the standard for $\mathrm{LH}$ assays. R Gonzalez was supported by a grant from the INTA Fellowship Program (Argentina).

\section{REFERENCES}

Chemineau P, Levy F, Thimonier J (1986) Effects of anosmia on LH secretion, ovulation and oestrous behaviour induced by males in the anovular Creole goat. Anim Reprod Sci 10, 125-132

Cohen-Tannoudji J, Locatelli A, Signoret JP (1986) Non-pheromonal stimulation by the male of $\mathrm{LH}$ release in the anoestrous ewe. Physiol Behav 36, 921-924

Cohen-Tannoudji J, Lavenet C, Locatelli A, Tillet $Y$, Signoret JP (1989) Non-involvement of the accessory olfactory system in the LH response of anoestrous ewes to male odour. $J$ Reprod Fertil 86, 135-144

Coquelin A, Bronson FH (1980) Secretion of luteinizing hormone in male mice: factors that influence release during sexual encounters. Endocrinology 106, 1224-1229

Garnier DH, Cotta Y, Terqui M (1978) Androgen radio-immunoassay in the ram: results of direct plasma testosterone and dehydroepiandrosterone measurement and physiological evaluation. Ann Biol Anim Biochim Biophys 18, 265-281

Gonzalez R, Orgeur P, Signoret JP (1988) Luteininizing hormone, testosterone and cortisol responses in rams upon presentation of oestrous females in the non-breeding season. Theriogenology 31, 1075-1086

Kamel F, Wright WW, Mock EJ, Frankel Al (1977) The influence of mating and related stimuli on plasma levels of luteinizing hormone, follicle stimulating hormone, prolactin and testosterone in the male rat. Endocrinology $101,421-429$ 
Katongole CB, Naftolin F, Short RV (1971) Relationship between blood levels of luteinizing hormone and testosterone in bulls and the effects of social stimulation. $J$ Endocrinol 50 , 457-466

Knight TW, Lynch PR (1980) Source of ram pheromones that stimulate ovulation in the ewe. Anim Reprod Sci 3, 133-136

Lindsay DR (1965) The importance of olfactory stimuli in the mating behaviour of the ram. Anim Behav 13, 75-78

Macrides F, Bartke A, Fernandez F, d'Angelo W (1974) Effect of exposure to vaginal odor and receptive females on plasma testosterone in the male hamster. Neuroendocrinology 15 , 355-364

Martin GB, Oldham CM, Lindsay DR (1978) Increased plasma $\mathrm{LH}$ levels in seasonally anovular merino ewes following the introduction of rams. Anim Reprod Sci 3, 125-132

Maruniak JA, Bronson FH (1976) Gonadotropic responses of male mice to female urine. Endocrinology 99, 963-969

Merriam GR, Wachter KW (1982) Algorithms for the study of episodic hormone secretion. Am J Physiol 243, 310-318

Pelletier J, Garnier DH, De Reviers MM, Terqui M, Ortavant R (1982) Seasonal variation in $\mathrm{LH}$ and testosterone release in rams of two breeds. J Reprod Fertil 64, 341-346

Poindron $P$ (1974) Méthode de suppression réversible de l'odorat chez la brebis et vérification de l'anosmie au moyen d'une épreuve comportementale. Ann Biol Anim Biochim Biophys 14, 41†-415

Poindron $P$, Cognie $Y$, Gayerie $F$, Orgeur $P$, Oldham CM, Ravault JP (1980) Changes in gonadotrophins and prolactin levels in isolated (seasonally or lactationally) anovular ewes associated with ovulation caused by the introduction of rams. Physiol Behav 25, 227-236
Sanford LM, Palmer WM, Howland BE (1974) Influence of sexual activity on serum levels of $\mathrm{LH}$ and testosterone in the ram. Can J Anim Sci $54,579-585$

Schanbacher BD, Orgeur P, Pelletier J, Signoret JP (1987) Behavioural and hormonal responses of sexually experienced lle-deFrance rams to oestrous females. Anim Reprod Sci 14, 293-300

Siegel S (1956) Non-Parametric Statistics For the Behavioral Sciences. MacGraw-Hill Kogakusha, Tokyo

Signoret JP, Lindsay DR (1982) The male effect in domestic mammals: effect on LH secretion and ovulation. Importance of olfactory cues. In: Olfaction and Endocrine Regulation (Breiphol W, ed) IRL Press, London, 63-72

Stevens J (1986) Applied Multivariate Statistics for the Social Sciences. L Erlbaum, New Jersey

Terqui M, Garnier DH, de Reviers MM, Huet S, Pelletier J (1980) La structure chronologique du dialogue entre l'hypophyse et les gonades chez les mammifères domestiques. In: Rythmes et Reproduction (Ortavant R, Reinberg A, eds) Masson, Paris, 59-72

Vandenbergh JG (1988) Pheromones and mammalian reproduction. In: The Physiology of Reproduction (Knobil E, Neil J et al, eds) Raven Press, NY, 1679-1696

Wilkinson L (1988) SYSTAT: The System for Statistics. Systat Inc, Evanston, IL

Wysocki CJ (1979) Neurobehavioral evidence for the involvement of the vomeronasal system in mammalian reproduction. Neurosci Behav Rev 3, 301-341

Wysocki CJ, Wellington JL, Beauchamp GK (1980) Access of urinary non volatiles to the mammalian vomeronasal organ. Science 207, 781-782

Wysocki C, Katz Y, Bernard R (1983) Male vomeronasal organ mediates female-induced testosterone surges in mice. Biol Reprod 28, 917-922 